seen on further ultrasonography and in biopsy specimens. Several treatments were required for each tumour, and injecting alcohol was often associated with considerable pain, whereas our patients did not report pain. These reports did not mention changes seen on ultrasound scans during or immediately after injection, which we found useful in laser treatment.

The most important advantage of the laser is its precision. It is unlikely that it will ever be possible to predict the extent of necrosis around a site at which absolute alcohol has been injected with an accuracy comparable to that already possible with the laser technique.

In conclusion, interstitial laser hyperthermia is feasible and seems to be safe. A multiple fibre system makes it feasible to treat tumours of clinically relevant size in the centre of solid organs. The real challenge for the future will be to develop diagnostic techniques that disclose exactly how far individual tumours extend in a wider range of organs (unlike the well defined tumours treated in this pilot study) and to establish the conditions of laser treatment that give complete tumour ablation with safe healing. This combination of technologies may be valuable for treating otherwise untreatable tumours in a range of solid organs and for the primary treatment of small neoplasms such as tumours of the prostate and adrenal glands.

We thank Mr R C G Russell, Mr P Hawlev, Mr W Slack, and the late Professor C G Clark for referring these patients and for permission to report these results. We also thank Dr $\mathrm{T}$ N Mills, Mr P Hill, and Miss L A Potter of the department of medical physics for their help. Mr Steger was supported by Living Technology Ltd, Glasgow, and Dr Bown by the special medical development on lasers from the Department of Health and by the Imperial Cancer Research Fund.

I Storm KF, Kaiser LR, Goodnight JE, et al. Thermotherapy for melanoma metastases in liver. Cancer 1982;49:1243-8.

2 Lindholm C-E, Kiellan E, Nilson P, Hertzman S. Microwave induced hyperthermia and radiotherapy in human superficial tumours-clinical results with a comparative study of combined treatment versus radiotherapy alone. Int f Huperthermia 1987;3:393-411.

3 Milligan AJ. Whole body hyperthermia induction techniques. Cancer Res 1984:44 (10) Suppl):4869-72.

4 Shipley WU, Nardi GL, Cohen AM, Clifton Ling C. Iodine-" implant and external heam irradiation in patients with localized pancreatic carcinoma. Cancer 1980;45:709-1

5 Dritchilo A, (irant EG, Harter KW, Holt RW, Rustigi SN, Rodgers JE. Interstitial radiation therapy for hepatic metastases: sonographic guidance for applicator placement. Am f Radiol 1986;164:275-8.

6 Bown SG. Phototherapy of tumors. World F Surg 1983;7:700-9.

7 Matthewson K, Coleridge-Smith P, O'Sullivan JP, Northfield TC, Bown SG. Biological effects of intrahepatic Nd-YAG laser photocoagulation in rats. Gastroenterology 1987:93:550-7.

8 Steger AC, Bown SG, Clarke CG. Interstitial laser hyperthermia-studies in the normal liver. Bry Surs 1988.75.598.

9 Matthewson K, Colcridge-Smith P, Northficld TC, Bown SG. Comparison of continuous wave and pulsed excitation for interstitial Nd-YAG induced hyperthermia. Lasers in Medical Science 1986;1:197-201.

10 Hashimoto D. Ultrasonography guided lasers and spheric lasers. In: Riemann

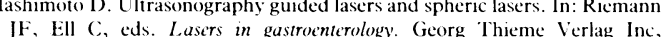
JF, Ell C, eds. Lasers in gastroenterolo
Stuttgart: Thicme Publishers, 1989:134-8.

11 Godlewski G, Sambuc P, Eledjam JJ, Pignodel C, Ould-Said A, Bourgeois JM. A new device for inducing deep localised vaporisation in liver with the $\mathrm{Nd}$ YAG laser. Lasers in Medical Science 1988;3:111-7.

12 Shina S, Yasuda $\mathrm{H}$, Muto $\mathrm{H}$, et al. Percutaneous ethanol injection in the treatment of liver neoplasms. Am $\mathcal{J}$ Radiol 1987; 149:949-52

13 Livraghi T, Festi M, Monti F, Salmi A, Vettori C. US-guided percutaneous alcohol injection of small hepatic and abdominal tumors. Radiology 1986;161:309-12

Accepted 31 Mav 1989

\title{
Effect of homoeopathic treatment on fibrositis (primary fibromyalgia)
}

\section{Peter Fisher, Alison Greenwood, E C Huskisson, Paul Turner, Philippe Belon}

\section{Departments of}

Rheumatology and Clinical

Pharmacology, St

Bartholomew's Hospital,

London EC1A 7BE

Peter Fisher, FFHOM, visiting

rheumatologist

Alison Greenwood, SRN,

clinical metrologist

EC Huskisson, FRCP, head of

rheumatology department

Paul Turner, FRCP, professor

of clinical pharmacology

Laboratoires Boiron, 69110 Ste Foy les Lyon, France

Philippe Belon, $\mathrm{MD}$, research director

Correspondence to: $\mathrm{Dr}$ Fisher.

Br Med f 1989:299:365-6
In scientific research negative results are often more difficult to interpret than positive ones, as was shown by a clinical trial in which the homoeopathic medicine Rhus toxicodendron $6 \mathrm{x}$ was compared with a placebo and fenoprofen in the treatment of osteoarthritis. The homoeopathic medicine was found to be ineffective whereas fenoprofen gave an improvement.' There were two interpretations: either the effects of homoeopathy are only a placebo effect - that is, a true negative - or the result was a false negative one because of flaws in the design. Another trial had previously suggested that homoeopathy was effective in rheumatoid arthritis.

We designed a trial to clarify these results by overcoming the methodological criticisms while retaining a rigorous design. The main problem in designing clinical trials of homoeopathy is that prescriptions are based on criteria such as the pattern of symptoms as well as the diagnosis. A clinical trial based solely on diagnosis is therefore inappropriate. In a pilot study we had shown that $R$ toxicodendron $6 \mathrm{c}$ was the most commonly indicated homoeopathic medicine for fibrositis in our patients, being indicated in $42 \%$.

\section{Patients, methods, and results}

We used the diagnostic criteria of Yunus et al for fibrositis. ${ }^{3}$ Only patients with this syndrome, in whom the homoeopathic medicine $R$ toxicodendron $6 \mathrm{c}$ was positively indicated were entered into the study. Thirty patients meeting the admission criteria were recruited in the rheumatology clinic of this hospital. The clinical characteristics of the patients were similar to those of other reported series regarding age, sex distribution, duration of symptoms, modalities, and number of tender points. The trial was double blind, placebo controlled, and of crossover design. After entry there was no further contact between the homoeopathic doctor and the patient until the treatment was finished. The clinical metrologist dispensed the treatment and performed the assessments and analyses blind. Patients received active treatment and an identical placebo for one month each in random sequence. The dose was two tablets sucked three times daily.

The active preparation was $R$ toxicodendron $6 \mathrm{c}$ (Boiron) prepared from a tincture of the leaves of poison oak diluted 1:99 in ethanol and then vigorously shaken. This process was repeated six times to give the $6 \mathrm{c}$ potency - a dilution of $10^{-12}$ of the tincture. This was then put up on $125 \mathrm{mg}$ lactose tablets (2\% volume per weight). Preparation was as specified in the French national pharmacopoeia. The placebo was identical lactose tablets to which only pharmaceutical ethanol had been added ( $2 \%$ volume per weight). Blind testing of the active and placebo preparations for a battery of drugs yielded negative results. Assessment comprised the number of tender spots, $10 \mathrm{~cm}$ visual analogue scales of pain and sleep, and overall assessment. Comparison was made between values at the end of active and placebo treatment periods.

The patients did better in all variables when they took active treatment rather than placebo. The number of tender spots was reduced by about a quarter $(\mathrm{p}<0.005)$. We reduced subjective data to nominal measurements (worse or better). If the null hypothesis were correct the direction of change after placebo and active treatment would be randomly distributed. Analysis showed a significant difference in favour of the homoeopathic medicine (table). Overall assessment also showed a preference for the active treatment, which was not significant. 
Assessment of patients with fibrositis after treatment with Rhus toxicodendron (active) and placebo

\begin{tabular}{lccc}
\hline & Placebo & Active & p Value \\
\hline $\begin{array}{l}\text { Mean No of tender points } \\
\begin{array}{l}\text { No of patients with improved pain } \\
\text { or sleep (visual analogue scores) }\end{array}\end{array}$ & $14 \cdot 1$ & $10 \cdot 6$ & $<0.005^{\star}$ \\
& 27 & 53 & $0.0052+$ \\
\hline Wilcoxon rank sum test. $\quad$ +Paired $t$ test. & &
\end{tabular}

\section{Comment}

Fibrositis (primary fibromyalgia) is a controversial condition but is becoming increasingly accepted. ${ }^{+}$It is difficult to treat. We showed that the homoeopathic medicine $R$ toxicodendron $6 \mathrm{c}$ was effective for a selected subgroup of patients with fibrositis. The improvement in tenderness, which is the best discriminator of fibrositis, ${ }^{5}$ was particularly distinct. The improvement experienced by our patients while receiving active treatment was at least as great as that reported for any other treatment that has been assessed double blind.

We thank Jean Boiron for his advice and encouragement.

1 Shipley M, Berry H, Broster G, Jenkins M, Clover A, Williams I. Controlled trial of homoeopathic treatment of osteoarthritis. Lancet 1983;i:97-8.

2 Gibson RG, Gibson SLM, MacNeill DA, Watson-Buchanan W. Homoeopathic therapy in rheumatoid arthritis: evaluation by double-blind clinical trial. Br f Clin Pharmacol 1980;9:453-9.

3 Yunus M, Masi AT, Calabro JJ, et al. Primary fibromyalgia (fibrositis): clinical study of 50 patients with matched normal controls. Semin Arthritis Rheum $1981 ; 11: 151-71$

4 Yunus $M B$. Fibromvalgia syndrome: new research on an old condition. Br.Med f 1989;289:474-5.

5 Wolfe F, Hawley DJ, Cathey MA, et al. Fibrositis: symptom frequency and criteria for diagnosis. $\mathcal{F}$ Rheumatol 1985;12:1159-68.

Accepted 28. April 1989)

\section{Incidence of transient nephrotic syndrome during pregnancy in diabetic women with and without pre-existing microalbuminuria}

\section{G Biesenbach, J Zazgornik}

Department of Medicine, General Hospital Linz, A 4020, Austria

G Biesenbach, MD, registrar in nephrology $\mathrm{J}$ Zazgornik, MD, professor of medicine

Correspondence to:

Dr Biesenbach.

BrMed J 1989;299:366-7
Considerably different changes in renal protein excretion have been reported in diabetic women during pregnancy. ${ }^{12}$ In pregnant diabetics with pre-existing macroproteinuria $(\geqslant 0.5 \mathrm{~g}$ protein in 24 hour urine samples) there is often a clear increase in the proteinuria, often resulting in development of the transient nephrotic syndrome. ${ }^{34}$ In diabetic women with albumin excretion $<30 \mathrm{mg} /$ day (normoalbuminuria) or $30-250 \mathrm{mg} /$ day (microalbuminuria) before pregnancy, however, the syndrome is rarely observed during pregnancy. We determined to what extent microalbuminuria (incipient diabetic nephropathy) affects the alterations of renal protein excretion and the variables of kidney function during and after pregnancy and the incidence of the syndrome during pregnancy in these women.

\section{Patients, methods, and results}

We investigated seven pregnant women with type I diabetes and pre-existing normoalbuminuria (mean (SD) age $22(5)$ years, mean (SD) duration of diabetes 10 (4) years) and seven pregnant type I diabetics with pre-existing microalbuminuria (mean (SD) age 23 (5) years, mean (SD) duration of diabetes 11 (3) years). All women delivered between 36 and 40 weeks' gestation. Before one woman became pregnant, during weeks 12 , $24,28,32$, and $36-40$ of pregnancy, and in weeks 4,12 , and 24 after delivery we measured serum creatinine concentration (autoanalyser), creatinine clearance, glycated haemoglobin concentration (Biorad), blood pressure (Riva Rocci), albumin concentration (immunodiffusion), and total protein concentration (Biuret method) in 24 hour urine samples.

In the seven diabetic women with pre-existing normoalbuminuria there was a $5 \cdot 9$-fold increase in albumin and a 5.7-fold increase in total protein excretion in urine during pregnancy. In the seven diabetic women with microalbuminuria we found a $5 \cdot 9$-fold increase in albumin excretion and a $10 \cdot 0$-fold increase in total protein excretion. After delivery the protein excretion fell to the values before pregnancy in all patients. The difference between the absolute increase of proteinuria in the two groups was significant $(\mathrm{p}<0.005$, unpaired $t$ test). Blood pressure and metabolic control did not differ significantly during pregnancy in both groups (table), and the variables of renal function did not differ between normoalbuminuric and microalbuminuric women. The transient nephrotic syndrome with protein excretion $>3 \mathrm{~g}$ in 24 hour samples of urine $(3.178 \mathrm{~g}, 4.907 \mathrm{~g}$, and $4.761 \mathrm{~g}$ ) occurred in three of the seven women with pre-existing microalbuminuria but in none of the seven with pre-existing normoalbuminuria.

\section{Comment}

The transient nephrotic syndrome is rare in pregnant diabetics without pre-existing heavy proteinuria and decreased glomerular filtration rate as well as in healthy pregnant women.' The extent to which albumin excretion before pregnancy influences the increase in proteinuria and the alterations of the kidney function during pregnancy has not, to our knowledge, been previously investigated in diabetic women.

In our patients with normoalbuminuria the increase in proteinuria during pregnancy remained within the physiological range seen in healthy pregnant women. ${ }^{+5}$ In the diabetic women with pre-existing microalbuminuria the increase in proteinuria during pregnancy was significantly higher. Obviously the glomerular basement membrane develops a greater permeability for protein during pregnancy in diabetic women with pre-existing microalbuminuria in com-

Urinary protein excretion and renal function before, during, and after pregnancy. Values are means $(S D)$

\begin{tabular}{|c|c|c|c|c|c|c|}
\hline & \multicolumn{3}{|c|}{ Diabetics with normoalbuminuria } & \multicolumn{3}{|c|}{ Diabetics with microalbuminuria } \\
\hline & $\begin{array}{c}\text { Before } \\
\text { pregnancy }\end{array}$ & $\begin{array}{l}\text { Third trimester } \\
\text { of pregnancy }\end{array}$ & $\begin{array}{l}24 \text { Weeks } \\
\text { after delivery }\end{array}$ & $\begin{array}{c}\text { Before } \\
\text { pregnancy }\end{array}$ & $\begin{array}{l}\text { Third trimester } \\
\text { of pregnancy }\end{array}$ & $\begin{array}{l}24 \text { Weeks } \\
\text { after delivery }\end{array}$ \\
\hline Albumin in urine (mg/day) & $12(3)$ & $71(34)$ & $13(4)$ & $80(45)$ & $478(247)$ & $114(74)$ \\
\hline Total protein in urine (g/day) & $0.073(0.056)$ & $0.417(0.142)$ & $0.096(0.073)$ & $0.233(0.186)$ & $2 \cdot 353(1 \cdot 211)$ & $0.239(0 \cdot 107)$ \\
\hline Serum creatinine $(u \mathrm{~mol} / \mathrm{l})$ & $79(13)$ & $68(10)$ & $85(7)$ & $71(15)$ & $63(9)$ & $79(13)$ \\
\hline Creatinine clearance $(\mathrm{ml} / \mathrm{s})$ & $1.72(0 \cdot 18)$ & $2.07(0 \cdot 118)$ & $1.72(0 \cdot 17)$ & $1.83(0.22)$ & $2 \cdot 12(0 \cdot 40)$ & $1.80(0 \cdot 28)$ \\
\hline Blood pressure $(\mathrm{mm} \mathrm{Hg})$ & $120(9) / 79(5)$ & $121(7) / 77(5)$ & $118(7) / 79(6)$ & $118(8) / 80(7)$ & $118(6) / 79(6)$ & $117(6) / 78(5)$ \\
\hline Glycated haemoglobin (\%) & $6 \cdot 2(1 \cdot 1)$ & $4 \cdot 7(0 \cdot 8)$ & $6 \cdot 2(0 \cdot 6)$ & $6.8(0.6)$ & $5 \cdot 4(0 \cdot 5)$ & $6.8(0.5)$ \\
\hline
\end{tabular}

